\title{
Production of Bio-Oil from Pyrolysis of Olive Biomass with/without Catalyst
}

\author{
Falah F. Bani Hani*, Mohammad M. Hailat \\ Department of Chemical Engineering, Al-Huson University College, Al-Balqa Applied University, Al-Huson, Jordan \\ Email: ^falahfah@yahoo.com
}

How to cite this paper: Hani, F.F.B. and Hailat, M.M. (2016) Production of Bio-Oil from Pyrolysis of Olive Biomass with/without Catalyst. Advances in Chemical Engineering and Science, 6, 488-499. http://dx.doi.org/10.4236/aces.2016.64043

Received: August 20, 2016

Accepted: October 16, 2016

Published: October 19, 2016

Copyright $\odot 2016$ by authors and Scientific Research Publishing Inc. This work is licensed under the Creative Commons Attribution International License (CC BY 4.0).

http://creativecommons.org/licenses/by/4.0/

\begin{abstract}
In this study olive biomass was pyrolysis in a $400 \mathrm{~cm}^{3}$ stainless steel reactor. It was externally heated by an electrical furnace in which the temperature is measured by a thermocouple inserted into the bed. The effect of the catalyst ratio to the biomass $(5 \%, 10 \%, 15 \%, 20 \%, 30 \%$ and $40 \%)$ on the pyrolysis yield was investigated and compared with the uncatalyzed pyrolysis yield product. The bio-oil products yield from the pyrolysis process was found to increase as the catalyst ratio increased. The bio-oil yield from the olive oil-cake, which was $36.1 \%$ without the catalyst, reached the maximum value of $39.3 \%$ on using activated catalyst at $10 \%$ by weight. The gas products yield was found to increase upon using catalyst compared to the non-catalytic pyrolysis. The reduction in the bio-oil yield product was accompanied with a significant reduction in the oxygen content. The pyrolysis oil was examined using chromatographic analysis techniques. The chemical characterization showed that the bio-oil obtained from olive oil cake might be potentially valuable as a fuel and chemical feedstock.
\end{abstract}

\section{Keywords}

Catalytic Pyrolysis, Bio-Oil, Olive Oil-Cake, Biomass

\section{Introduction}

Energy demand in the world continues to increase with the increase in population and economic development. In order to generate the necessary energy to supply the increasing energy demand and also to comply with the regulations related to environmental pollution, the use of biomass as a renewable source of energy is becoming more and more important. Olive oil-cake (OC), which is a waste of olive oil-mill, is an important biomass generated in Mediterranean countries. OC is available in large 
amounts at a very low cost. Vegetable oils and OC can be considered as an alternative source of fuel, which do not contain sulfur. The cake still has a commercial value owing to the oil it contains. Up to $40 \mathrm{~kg}$ of cake is obtained from $100 \mathrm{~kg}$ of olives. Its characteristics depend on the process utilized to extract oil, and differ according to whether pressure, centrifuging or selective filtration is used, and whether the stone (pit) was removed from the olives. Typical cake arising as a result of pressure extraction contains from $4 \%$ to $5 \%$ oil when well exhausted and from $8 \%$ to $12 \%$ when coming from a classical press [1] [2]. An analysis of the content of this cake gives an average of sulfur content of about $0.05-0.1 \mathrm{wt} \%$, water $25 \%$, nitrogenated materials $4.4 \%$, fatty material $4 \%$, non-nitrogenated extractable material $20 \%$, gross cellulose $40 \%$, and ash $6.6 \%$. The water content falls to $15 \%-20 \%$ after some days of exposure to air [1] [3] [4]. Olive oilcake actually is a waste and like other wastes can cause problems if suitable and acceptable disposal measures are not taken. Efficient use of OC in energy production solves the two problems in one step: clean energy production and acceptable disposal of olivemill wastes. OC can be burned alone or can be combined with other combustible materials, like low calorific value lignite coals. Therefore, it is of prime importance to be able to burn this waste in producing clean energy in the regions where olive trees are grown. However, an appropriate technology must be employed to avoid the production of pollutants and other problems while maximizing process efficiency. In the literature, several studies have been reported on the combustion of OC in a fluidized bed combustor for energy production. OC has either been used alone or in combination with oil shale or diesel oil [1] [2]. Olive oil-cake is an important contributor to the world economy. Today, various forms of OC energy are consumed all over the world. OC provides a clean, renewable source of energy that could dramatically improve the environment, economy and energy security. Bioenergy does not contribute to climate change through emissions to the atmosphere of carbon dioxide or other "green-house gases" [3]-[5]. Valuing the environmental and social contributions that OC inherently makes can also help increase its use [6]. In developing countries, the use of OC is of high interest, since these countries have economies largely based on agriculture and forestry. The use of these materials will depend on the state of the art of safe and economic technologies able to transform them into manageable products [7] [8]. In this way, thermochemical biomass conversion processes such as pyrolysis, gasification and liquefaction are the most appropriate [9]. However, gasification of agricultural residues is more difficult because of bed transport, partial ash sintering, non-uniform flow distribution and the presence of a muddy phase in the effluents [10]. Pyrolysis offers efficient utilization of OC, which is of particular importance for agricultural countries with vastly available biomass by-products [11]. The pyrolysis process conditions can be optimized to maximize the production of liquids (tar, bio-oil), solids (char) or gases whose distribution depends on the experimental conditions applied especially temperature and heating rate [7]. In particular, the production of pyrolysis liquids has been investigated with the aim of using the liquid product directly in fuel applications or by upgrading, producing refined fuels and/or chemical products [12]-[17]. Numerous studies regarding liquid 
fuel production from various sources of biomass have demonstrated that an oil product can be obtained from OC in significant yields [2]-[4] [7]. Their direct use as conventional fuels may present some difficulties due to their high viscosity, poor heating value, corrosiveness and instability. Upgrading pyrolytic oils, a necessary process before using them as a regular fuel, essentially involves removal of oxygen. Currently, two methods have been proposed for this process. The first method is a typical catalytic hydrotreatment with hydrogen and carbon monoxide under high pressure and/or in the presence of hydrogen donor solvents. The second method utilizes cracking catalysts (zeolites, silica-alumina and molecular sieves) under atmospheric pressure without hydrogen [15] [18]. The products obtained from this process depend on the characteristics of the catalyst used. The different catalysts are characterized by different operating conditions and different product distributions. Catalysis in this context is used mainly to crack higher molecular weight compounds to a lighter more commercially valuable product. Catalysts for use in pyrolysis or gasification processes may be divided into two distinct groups: the first group of catalysts (primary catalyst) is added directly to the OC before the experiments. The addition is either by wet impregnation of the raw material or by dry mixing of the catalyst with it. They operate under the same temperature with the reactor and are usually nonrenewable (in-bed mode) [19] [20]. This type of operation permits the immediate contact of the evolved pyrolysis vapors with the catalyst. The second group of catalysts is placed in a secondary reactor located downstream from the pyrolysis reactor [19] [21] [22]. However, only a few studies have dealt with olive residues, although these could be a source for fuels and energy production as well as activated carbon production [23]. Olive oil-cake is the solid residue obtained from pressing the olives. In recent years, OC production in Jordan has increased due to the increase of olive oil production. These residues are not used for the production of energy and other products in Jordan and thus constitute a source of environmental problems caused by their accumulation and disposal; it is, therefore, interesting to study the possibilities of their exploitation as a source of energy. Reuse of these residues could solve pollution problems by means of pyrolysis to recover energy or valuable compounds [1] [24]. Olive cake was used in this study because it is a good source of energy and olive trees exist abundantly in the Mediterranean countries [23] [25]. The effect of using different catalyst ratios on the products yield was investigated. The composition of the bio-oil fuel obtained was analyzed and its usability as a potential source of renewable fuel was also investigated.

\section{Materials and Methods}

\subsection{Material}

\subsubsection{Biomass}

The olive-oil cake sample investigated in this study was taken from olive oil factories located in around the city of Ajllun in the north of Jordan. Olive-oil cake, the biomass remaining as a byproduct of industrial processes after extracting removal of oil by pressing, was used in the work. Prior to use, the sample was air dried, ground with a 
high-speed rotary cutting mill and then screened to give the fractions of $0.425<\mathrm{Dp}<$ $0.600 \mathrm{~mm}$ particle size. Table 2 shows the proximate and ultimate analyses of the samples. Proximate analyses of the raw material having an average particle size were performed according to the American Society for Testing and Materials (ASTM) procedure. Elemental analyses were performed on olive residue samples to determine the elemental composition. LECO CHNS 932 elemental analyzer was used to determine the weight fractions of carbon, hydrogen and nitrogen, and the weight fraction of oxygen was considered to be the balance. Oil, cellulose, hemicellulose, lignin, extractives and protein contents of the samples were determined. Protein content was determined by the Kjeldahl method using Labconco Rapid still-2 and Nx6.25 as the conversion factor. Determination of ash and moisture was performed according to ASTM Standards (D-1102-84 and D-2016-74). Calorific value of olive residue was calculated as 20.7 $\mathrm{MJ} / \mathrm{kg}$ with Du-Long's formula with the known values of elemental composition [25].

\subsubsection{Catalyst Preparation}

Natural zeolite was selected as a catalyst for our application. There is an abundance of sediment beds in east Jordan. The samples were taken from the north-east region and, and the purity was about $95 \%$. For activation, it was calcined at $400^{\circ} \mathrm{C}$ for 3 hours [26]. Catalyst specifications and compositions are given in Table 1.

\subsection{Pyrolysis Experiments}

The pyrolysis experiments were performed by dry mixing of the catalyst with biomass samples at in-bed mode in the pyrolysis atmosphere. In this study, a stainless steel reactor with the volume of $400 \mathrm{~cm}^{3}$ was used to conduct the pyrolysis experiments. It was externally heated by an electrical furnace in which the temperature is measured by a thermocouple inserted inside the bed. The experiments were conducted to determine the effect of catalyst ratio on the pyrolysis yields biomass sample. During experiments, $20 \mathrm{~g}$ of OC sample with an average particle size of $0.425-0.600 \mathrm{~mm}$ was mixed with different catalyst weight percentages (5\%,10\%, 15\%, 20\%, 30\% and $40 \% \mathrm{w} / \mathrm{w})$ and then placed into the reactor. The optimum experimental conditions determined in a previous study were a final pyrolysis temperature of $500^{\circ} \mathrm{C}$, a heating rate of $8^{\circ} \mathrm{C} / \mathrm{min}$, a sweeping gas flow rate of $150 \mathrm{ml} / \mathrm{min}$ and a mean particle size of $0.425<\mathrm{Dp}<0.600$ $\mathrm{mm}$ [20] [26] [27]. Experimental apparatus was held at final pyrolysis temperature for either a minimum of $30 \mathrm{~min}$ or until no further significant release of gas was observed. The flow of gas released was observed and measured using a soap film flow meter for

Table 1. Catalyst specifications and composition.

\begin{tabular}{cccccc}
\hline \multicolumn{2}{c}{ Catalyst specifications } & \multicolumn{5}{c}{ Catalyst composition, \% } \\
\hline Pore diameter $\left(\mathrm{A}^{\circ}\right)$ & 33.12 & $\mathrm{SiO}_{2}$ & 65.42 & $\mathrm{MgO}$ & 1.09 \\
Particle diameter $(\mathrm{mm})$ & $\mathrm{Dp}>1.6$ & $\mathrm{Al}_{2} \mathrm{O}_{3}$ & 24.21 & $\mathrm{CaO}$ & 2.95 \\
Surface area $\left(\mathrm{m}^{2} \cdot \mathrm{g}^{-1}\right)$ & 69.12 & $\mathrm{TiO}_{2}$ & 0.02 & $\mathrm{H}_{2} \mathrm{O}$ & 12.1 \\
Density $\left(\mathrm{kg} \cdot \mathrm{m}^{-3}\right)$ & 2150 & $\mathrm{Fe}_{2} \mathrm{O}_{3}$ & 1.38 & - & - \\
\hline
\end{tabular}


the duration of experiments. The liquid products (bio-oil and water) were collected by condensing in cold traps maintained at about $0^{\circ} \mathrm{C}$ and recovered by washing with dichloromethane. The aqueous phase in the liquid product was separated using separator funnel. The bio-oil and solvent mixture was passed over dry sodium sulfate to make it water-free and then the solvent was removed from bio-oil by rotavapour. After pyrolysis, the char was weighed. The gas yield was calculated from the material balance. In this study, all the yields are expressed on a dry ash-free basis and the average yields were obtained from triplicate experiments with a standard deviation of $<0.5 \mathrm{wt} \%$.

\subsection{Characterization}

Proximate and elemental analysis was carried out on the olive-oil cake and elemental composition of bio-oils Table 2 and Table 3. The bio-oil analyzed in this study has been obtained from the experimental condition that has given maximum bio-oil yield. The elemental compositions and caloric values of the pyrolysis oil were determined using Gallenkamp Auto Adiabatic Bomb Calorimeter (ASTM 240). The chemical class composition of the oil was determined by liquid column chromatographic fractionation. The oil was separated into two fractions as pentane-soluble and insoluble compounds (asphaltenes) by using $100 \mathrm{ml}$ of pentane. The pentane-soluble material was further separated on activated silica gel pretreated at $105^{\circ} \mathrm{C}$ for $2 \mathrm{~h}$ prior to introduction in a $20 \mathrm{~cm}$ height and $25 \mathrm{~mm}$ i.d. column. The column was eluted successively with n-pentane, toluene, and methanol to produce aliphatic, aromatic, and polar fractions, respectively. Each fraction was dried and weighted and then subjected to elemental analyses. The n-pentane subfraction was analyzed using a Hewlett-Packard 5890 series II gas chromatography with flame ionization detection (FID) detector. The pyrolysis oil was fractionated by distillation according to ASTM D285-62 in the ranges of $140^{\circ} \mathrm{C}$ $240^{\circ} \mathrm{C}, 240^{\circ} \mathrm{C}-350^{\circ} \mathrm{C}$ for simulated distillation of the resultant fractions by GC (HP 5890 Series II) according to ASTM D 2887-84 in order to compare the distillation curves of the pyrolysis product distillates with those of conventional transport fuel.

Table 2. The proximate and elemental analyses of the olive-oil cake.

\begin{tabular}{cccccccccc}
\hline \multicolumn{4}{c}{ Proximate analysis \% } & \multicolumn{1}{c}{ Ultimate analysis \% } \\
\hline $\begin{array}{c}\text { Moisture } \\
\text { content } \%\end{array}$ & $\begin{array}{c}\text { Volatile } \\
\text { S }\end{array}$ & $\begin{array}{c}\text { Fixed } \\
\text { C }\end{array}$ & Ash & C & H & N & O & H/C & $\begin{array}{c}\text { Calorific values } \\
\mathrm{MJ} / \mathrm{kg}\end{array}$ \\
\hline 6.8 & 67.2 & 21.6 & 4.4 & 53.4 & 7.5 & 1.7 & 37.4 & 1.7 & 20.7 \\
\hline
\end{tabular}

Table 3. Elemental composition of bio-oils (wt\%).

\begin{tabular}{ccccccc}
\hline $\begin{array}{c}\text { Calorific values } \\
\mathrm{MJ} / \mathrm{kg}\end{array}$ & $\mathrm{H} / \mathrm{C}$ & $\mathrm{O}$ & $\mathrm{N}$ & $\mathrm{H}$ & $\mathrm{C}$ & Bio-oil \\
\hline 32.16 & 1.65 & 22.02 & 2.01 & 8.98 & 66.68 & $\begin{array}{c}\text { Olive oil-cake without } \\
\text { catalyst }\end{array}$ \\
43.05 & 1.85 & 17.66 & 3.02 & 10.62 & 68.79 & $\begin{array}{c}\text { Olive oil-cake with activated } \\
\text { catalyst by } 10 \text { wt } \%\end{array}$ \\
\hline
\end{tabular}




\section{Results and Discussion}

\subsection{Product Yields}

The biomass sample was pyrolysis to determine the effect of catalyst ratio (5\%, $10 \%$, $15 \%, 20 \%, 30 \%$ and $40 \%$ ) on the pyrolysis yield. The results are given in (Figure 1). The bio-oil yields slightly increased as the catalyst ratio increased. The bio-oil yield from the OC, which was $36.1 \%$ without catalyst, reached the maximum value of $39.3 \%$ upon using catalyst at $10 \%$ by weight. The bio-oil yield increased about $3.2 \mathrm{wt} \%$ at catalytic pyrolysis conditions. When the catalyst ratio increased up to $40 \%$ by weight the bio oil decreased. The gas product yields with catalyst increased compared to the non-catalytic pyrolysis. The gas yield, obtained as $17.1 \%$ without catalyst, increased to $23.5 \%$ with $40 \%$ (wt/wt) activated catalyst. The water yield, which was $16.2 \%$ without catalyst, reached the maximum value of $22.4 \%$ on using catalyst at $30 \%$ by weight. Pyrolysis products obtained confirm that the catalyst promotes the depolymerization processes to yield a strong carbonization (high solid yields) or a strong liquid phase cracking (low liquid yields) and hence a higher hydrogen formation, since this gas wasformed from liquid cracking [1] [24]. The water yields with catalyst increased compared to the noncatalytic experiments.

The aqueous product was the main result of oxygen removal from the biomass pyrolysis vapors for the Y-zeolite and activated catalysts [28]. The bio-oil yields oxygen content was low because some of it was converted to $\mathrm{CO}_{2}$ and $\mathrm{CO}$ due to the presence of coke and hydrocarbon gas at the surface of the catalyst [18]. Pyrolysis char values did not change significantly in samples by using different catalyst ratios. Catalyst ratio more than $10 \%$ by weight exhibited a significant effect on decreasing the bio-oil yield compared to the non-catalytic case. These results are consistent with those obtained in previous studies [16] [20] [24] [29].

\subsection{Chemical Composition}

Olive biomass was found to be consisting of $12.8 \%$ oil, $31.1 \%$ cellulose, $15.6 \%$ hemicel-

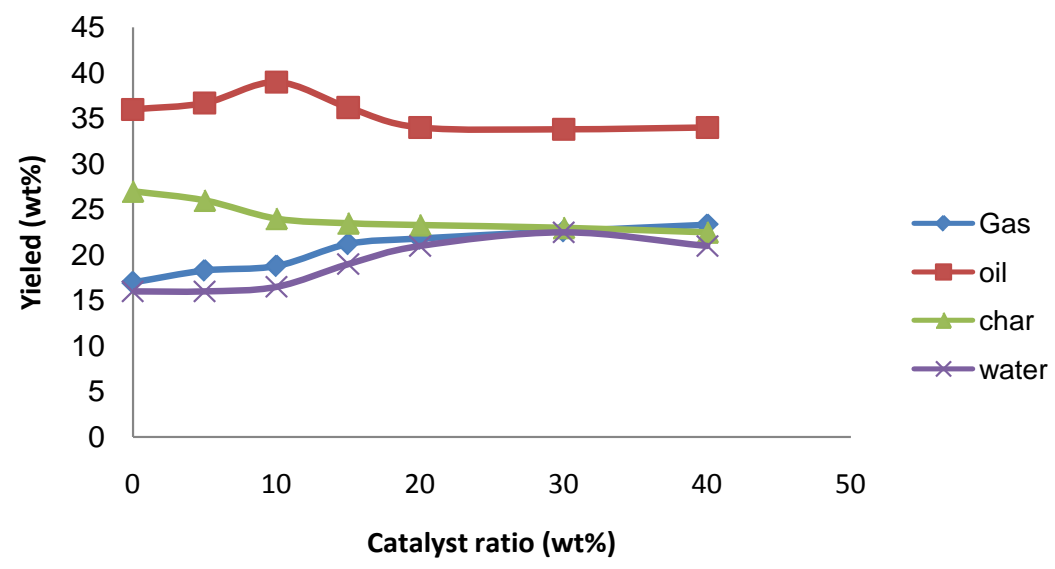

Figure 1. Effect of activated catalyst ratio on pyrolysis yields (pyrolysis temperature of $500^{\circ} \mathrm{C}$, heating rate of $8^{\circ} \mathrm{C} / \mathrm{min}$ and nitrogen flow rate of $150 \mathrm{ml} / \mathrm{min}$ ). 
lulose, $25.2 \%$ lignin, $28.1 \%$ extractives and $10.5 \%$ protein [25]. The proximate analyses and the elemental compositions of the olive-oil cake are given in Table 2. The properties of bio-oils derived from OC are given in Table 3. As can be seen from these tables, Bio-oil is characterized by low oxygen content with a higher $\mathrm{H}=\mathrm{C}$ ratio than original feedstock. The significant decrease in oxygen content of the bio-oil is important compared to the original feedstock because the high oxygen content is not attractive for the production of transport fuels [25]. Further comparison of the H/C ratios with conventional fuels indicates that the $\mathrm{H} / \mathrm{C}$ ratios of the bio-oils obtained in this work lie between light and heavy petroleum products in this respect. It can be seen in Table 2 that the $\mathrm{C}$ and $\mathrm{H}$ values increased and oxygen content decreased in the bio-oils obtained by catalytic pyrolysis compared with non-catalytic experiments. The elemental composition is consistent with cellulose and other polysaccharides as the major class of material present. It can be seen in Table 3 that the $\mathrm{C}$ and $\mathrm{H}$ values increased and oxygen content decreased in the bio-oils obtained by catalytic pyrolysis compared with non-catalytic experiments. The calorific values of the bio-oil obtained by applying the optimum conditions stated above were determined as $32.15 \mathrm{Mj} / \mathrm{kg}$ and $37.33 \mathrm{Mj} / \mathrm{kg}$ for the products obtained from the pyrolysis of OC without using a catalyst and with catalyst, respectively. When the calorific values of the bio-oils obtained from catalytic pyrolysis are compared with the bio-oils of the non-catalytic process, it can be seen that the addition of catalyst to raw material provided higher calorific values. As noted in the literature, catalytic treatment caused removal of oxygen, increased heating value and stability [18] [24] [30]. Caloric value of the bio-oil is also very close to those of petroleum fractions (Table 3).

Bio-oil was separated into two fractions as pentane-soluble and insoluble compounds (asphaltenes) by using pentane. The pentane-soluble material was further separated by adsorption chromatography. The results of adsorption chromatography of the oils (Table 4) showed that the pyrolysis oil consists of $52 \mathrm{wt} \% \mathrm{n}$-pentane soluble, while $\mathrm{n}$-pentane soluble obtained with non-catalytic pyrolysis of OC is in the ratio of $82.6 \%$, it reached $78.1 \%$ on using catalyst. The aliphatic fractions increased upon using of activated catalyst compared with the aliphatic fraction value for non-catalytic process. The aromatic fractions were down from $52.1 \%$ to $41.8 \mathrm{wt} \%$ when activated catalyst was used. On other hand, the polar fraction yields, that was $29.3 \mathrm{wt} \%$, decreased to 25.3 wt $\%$ when activated catalyst was used. As noted in the literature, catalytic pyrolysis

Table 4. Yields of column chromatographic fractions of bio-oils (wt \%).

\begin{tabular}{ccccccc}
\hline $\begin{array}{c}\text { Methanol } \\
(\%)\end{array}$ & $\begin{array}{c}\text { Toluene } \\
\text { (\%) }\end{array}$ & $\begin{array}{c}\text { Pentane } \\
(\%)\end{array}$ & $\begin{array}{c}\text { Pentane } \\
\text { insoluble oil } \\
\text { fraction }\end{array}$ & $\begin{array}{c}\text { Pentane } \\
\text { soluble oil } \\
\text { fraction }\end{array}$ & Bio-oil & Precursor \\
\hline 29.3 & 52.1 & 20.6 & 19.6 & 82.6 & $\begin{array}{c}\text { Without } \\
\text { catalyst }\end{array}$ & Olive cake \\
& 41.8 & 35.8 & 22.7 & 78.1 & $\begin{array}{c}\text { With activated } \\
\text { catalyst by } 10\end{array}$ & Olive cake \\
& & & & & wt\% & \\
\hline
\end{tabular}


products of the bio-oils include more aromatics or aliphatic compared with uncatalysed products [28] [29]. When these results are taken into account in the view of the effect of catalyst on the fractions, it is evident that activated catalyst has an important role in affecting the chemical composition compared with the non-catalytic experimental results in bio-oil. The important decrease in the oxygen content of the oil compared with the non-catalytic is important because the high oxygen content is not attractive for the production of transport fuels. Bio-oil contains a low percentage mass fraction of aliphatic and aromatic subfractions and a high concentration of polar material. Chemicals that have been reported as recovered include polyphenols for resins with formaldehyde and others GC chromatogram for bio-oils from catalytic pyrolysis is given in (Figure 2). The ranges of the straight-chain alkanes are C10-C29 in the bio-oil. Although the distribution of the hydrocarbon is alike, the intensities are different and the abundance of n-alkane distribution is observed in the oil obtained with catalyst. According to the GC analysis it can be concluded that the compounds obtained during the process of catalytic pyrolysis are predominantly saturated structures. This is probably due to the conversion of unsaturated hydrocarbons (olefins) to saturated hydrocarbons (alkanes), while desorption of low molecular products take place. The GC chromatogram of the pentane sub fraction shows that the carbon distribution lies between C13 and C28. When these results are compared with the diesel chromatogram, carbon distribution of the pentane sub fraction is found similar to diesel fuel.

To further assess the compatibility of the oil with current utilized transport fuel, simulated distillation curves (Figure 3 ) of the pyrolysis oil was obtained. Yields of $8 \%$, $39 \%, 32 \%$, and $21 \%$ were obtained for fractions boiling under $140^{\circ} \mathrm{C}, 140^{\circ} \mathrm{C}-240^{\circ} \mathrm{C}$, $240^{\circ} \mathrm{C}-350^{\circ} \mathrm{C}$ and above $350^{\circ} \mathrm{C}$, respectively. The fractions boiling at $140^{\circ} \mathrm{C}-240^{\circ} \mathrm{C}$ and $240^{\circ} \mathrm{C}-350^{\circ} \mathrm{C}$ were compared with kerosene and diesel fuel respectively. The simulated distillation curves showed that the whole $140^{\circ} \mathrm{C}-240^{\circ} \mathrm{C}$ fraction was quite

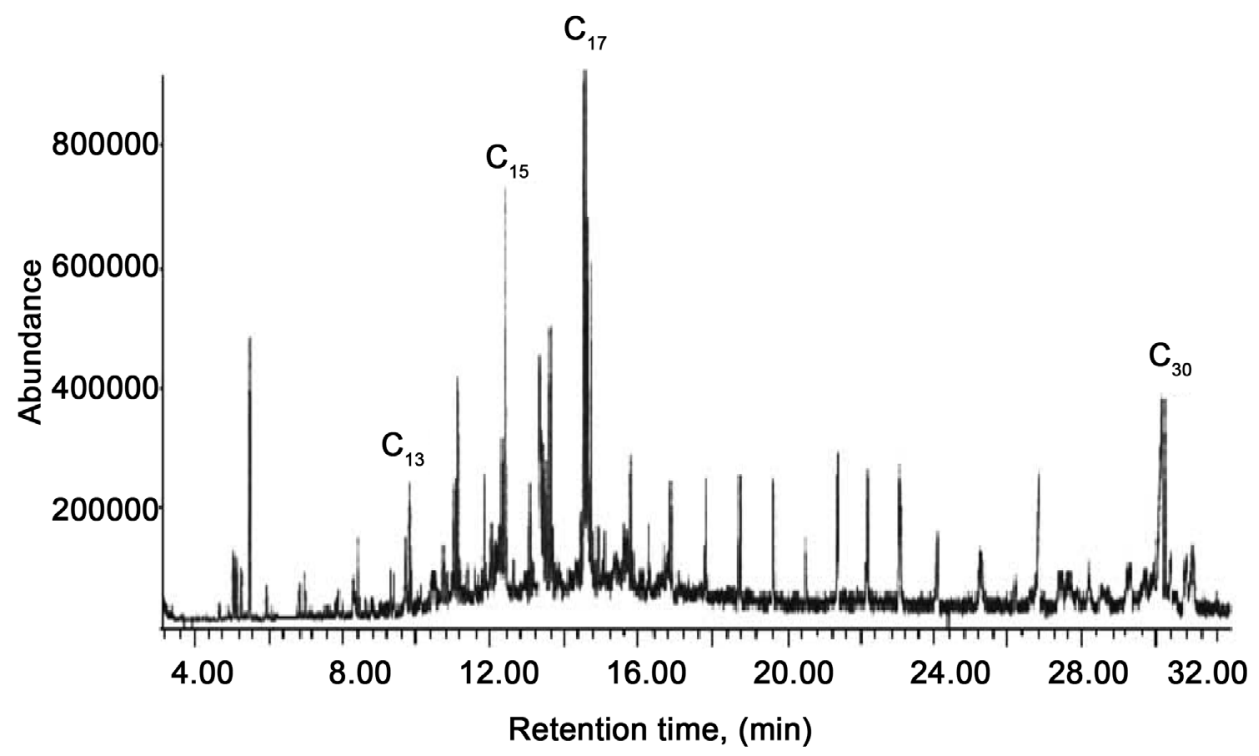

Figure 2. Gas chromatogram of the n-pentane sub fraction. 


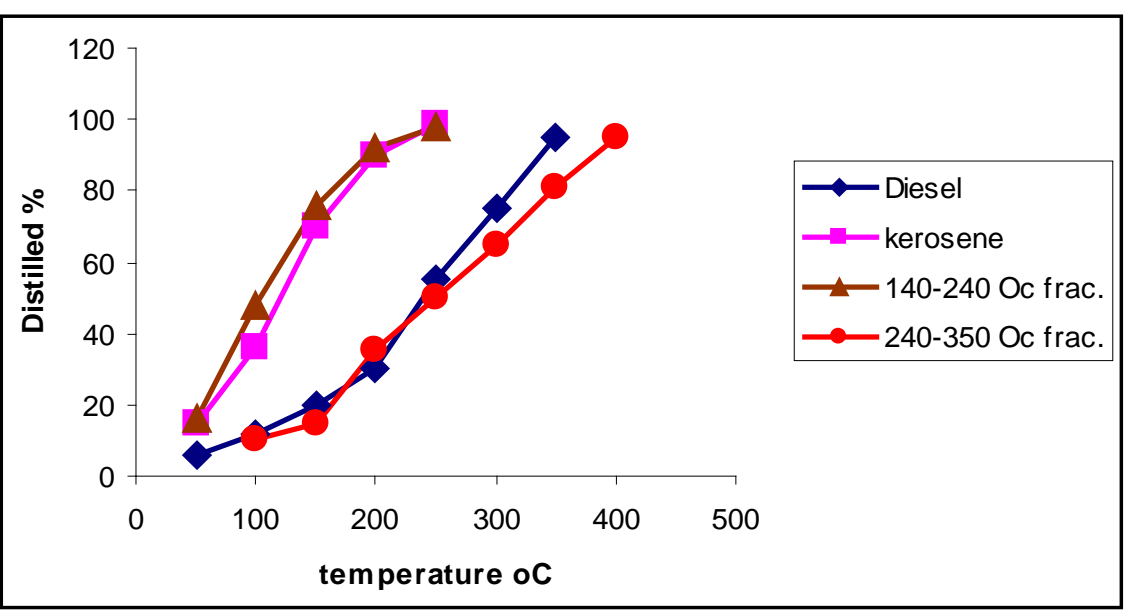

Figure 3. Comparison of simulated distillation curves.

similar to kerosene and the $240^{\circ} \mathrm{C}-350^{\circ} \mathrm{C}$ fraction was similar to diesel fuel.

Shown in Table 5, the initial boiling point (IBP) of the biodiesel was $78^{\circ} \mathrm{C}$ compared to $66^{\circ} \mathrm{C}$ for diesel and for fraction boiling at $140^{\circ} \mathrm{C}-240^{\circ} \mathrm{C}$ was $44^{\circ} \mathrm{C}$ compared to $47^{\circ} \mathrm{C}$ for kerosene. A much narrower boiling range but higher value could be observed in the case of the biodiesel than in the case of diesel. The boiling temperatures kept almost constant at a value of about $300^{\circ} \mathrm{C}$ from $30 \%$ fraction to $70 \%$ fraction, while it increased in the case of fractions boiling at $140^{\circ} \mathrm{C}-240^{\circ} \mathrm{C}$, which was an average of $30^{\circ} \mathrm{C}-35^{\circ} \mathrm{C}$. The boiling temperature for fraction distillated by ASTM D285-62 was similar for the biodiesel obtained from this study to diesel, which had an $8^{\circ} \mathrm{C}-10^{\circ} \mathrm{C}$ different boiling range from $10 \%$ to $90 \%$.

The final boiling point (FBP) of fractions boiling at $140^{\circ} \mathrm{C}-240^{\circ} \mathrm{C}$ is very close to those of kerosene. They were $245^{\circ} \mathrm{C}$ and $244^{\circ} \mathrm{C}$, respectively, in contrast, FBP of biodiesel was much lower than in diesel. They were $346^{\circ} \mathrm{C}$ and $368^{\circ} \mathrm{C}$ for the biodiesel and for diesel, respectively. The lower FBP for the biodiesel may be, because the double bond of unsaturated of alkyl chains could be polymerized at high temperatures [27] [28].

\section{Conclusion}

In this study, the effect of the catalyst on product and chemical composition of the bio-oil products from biomass samples was investigated. The bio-oil yield was decreased when compared with non-catalytic experiments for biomass sample with catalyst. The addition of activated catalyst provided a higher calorific value to the bio-oil. Low oxygen content and high H/C ratio characterized the bio-oil. Comparison of the $\mathrm{H} / \mathrm{C}$ ratios with conventional fuels indicates that the $\mathrm{H} / \mathrm{C}$ ratio of the bio-oils is very similar to that of light petroleum products. Chemical class fraction and elemental analysis of the bio-oil showed that the oxygenated species decreased upon using different ratios of catalyst in the experiment. These features are advantageous for its stability, handling and for upgrading purposes. All these factors favor the use of the obtained 
Table 5. Fractions distillation of pyrolysis oil according to ASTM D285-62.

\begin{tabular}{|c|c|c|c|c|}
\hline \multirow{2}{*}{ Fraction distillation, \% } & \multicolumn{4}{|c|}{ Boiling temperature } \\
\hline & $140^{\circ} \mathrm{C}-240^{\circ} \mathrm{C}$ & $240^{\circ} \mathrm{C}-350^{\circ} \mathrm{C}$ & Diesel & Kerosene \\
\hline IBP & 44 & 78 & 66 & 47 \\
\hline $10 \%$ & 68 & 157 & 167 & 75 \\
\hline $30 \%$ & 148 & 290 & 210 & 156 \\
\hline $50 \%$ & 157 & 300 & 272 & 164 \\
\hline $70 \%$ & 180 & 310 & 330 & 186 \\
\hline $90 \%$ & 238 & 340 & 342 & 240 \\
\hline FBP & 245 & 346 & 368 & 244 \\
\hline
\end{tabular}

bio-oil as fuel. In conclusion, the worldwide continuous increase in the demand for oil will play an important role in the realization of the need for alternative renewable resources of energy and bio-oil could be one of them.

\section{References}

[1] Demiral, I. and Sensöz, S. (2008) The Effects of Different Catalysts on the Pyrolysis of Industrial Wastes (Olive and Hazelnut Bagasse). Bioresource Technology, 99, 8002-8007. http://dx.doi.org/10.1016/j.biortech.2008.03.053

[2] Soensoz, S., Demiral, I. and Hassan, G. (2006) Olive Bagasse (Olea europea L.). Pyrolysis Bioresource Technology, 97, 429-436. http://dx.doi.org/10.1016/j.biortech.2005.03.007

[3] Antonakou, E., Lappas, A., Nilsen, M., Bouzga, A. and Stocker, M. (2006) Evaluation of Various Types of A1-MCM-41 Materials as Catalysts in Biomass Pyrolysis for the Production of Bio-Fuels and Chemicals. Fuel, 85, 2202-2212. http://dx.doi.org/10.1016/j.fuel.2006.03.021

[4] Demirbas, A., Agolar, A., Akdeniz, F. and Gullu, D. (2000) Conversion of Olive Husk to Liquid Fuel by Pyrolysis and Catalytic Liquefaction. Energy Source, 22, 631-639. http://dx.doi.org/10.1080/00908310050045582

[5] Islam, M., Praveen, M. and Haniu, H. (2010) Properties of Sugarcane Waste Derived BioOils Obtained by Fixed Bed Tube Fired Heating Pyrolysis. Bioresource Technology, 101, 4162-4168. http://dx.doi.org/10.1016/j.biortech.2009.12.137

[6] Chum, H.L. and Overend, R.P. (2001) Biomass and Renewable Fuels. Process Technology, 71, 187-195. http://dx.doi.org/10.1016/S0378-3820(01)00146-1

[7] Lappi, H. and Alén, R. (2011) Pyrolysis of Vegetable Oil Soaps Palm, Olive, Rapeseed and Castor Oils. Journal of Analytical and Applied Pyrolysis, 91, 154-158. http://dx.doi.org/10.1016/j.jaap.2011.02.003

[8] Bridgwater, A.V. (1999) Principles and Practice of Biomass Fast Pyrolysis Processes for Liquids. Journal of Analytical and Applied Pyrolysis, 51, 3-22.

http://dx.doi.org/10.1016/S0165-2370(99)00005-4

[9] Encinar, J., Beltran, F., Bernalte, A., Ramiro, A. and Gonzalez, J. (1996) Pyrolysis of Two Agricultural Residues: Olive and Grape Bagasse. Influence of Particle Size and Temperature. Biomass Bioenergy, 11, 397-409. http://dx.doi.org/10.1016/S0961-9534(96)00029-3

[10] Giannakopoulou, K., Lukas, M. and Vasiliev, A. (2010) Conversion of Rapeseed Cake into Bio-Fuel in a Batch Reactor: Effect of Catalytic Vapor Upgrading. Microporous and Mesoporous Materials, 128, 126-135. http://dx.doi.org/10.1016/j.micromeso.2009.08.022 
[11] Ucar, S. and Ozkan, A.R. (2008) Characterization of Products from the Pyrolysis of Rapeseed Oil Cake. Bioresource Technology, 99, 8771-8776.

http://dx.doi.org/10.1016/j.biortech.2008.04.040

[12] Demirbas, A. (2001) Yields of Hydrogen-Rich Gaseous Products via Pyrolysis from Selected Biomass Samples. Fuel, 80, 1885-1891. http://dx.doi.org/10.1016/S0016-2361(01)00070-9

[13] Volli, V. and Singh, R. (2012) Production of Bio-Oil from De-Oiled Cakes by Thermal Pyrolysis. Fuel, 96, 579-585. http://dx.doi.org/10.1016/j.fuel.2012.01.016

[14] Mullen, C.A., Boateng, A.A. and Goldberg, N.M. (2010) Bio-Oil and Bio-Char Production from Corn Cobs and Stover by Fast Pyrolysis. Biomass Bioenergy, 34, 67-74. http://dx.doi.org/10.1016/j.biombioe.2009.09.012

[15] Williams, P. and Chishti, H. (2000) Two Stage Pyrolysis of Oil Shale Using a Zeolite Catalyst. Journal of Analytical and Applied Pyrolysis, 55, 217-234. http://dx.doi.org/10.1016/S0165-2370(00)00071-1

[16] Williams, P. and Nugranad, N. (2000) Comparison of Products from the Pyrolysis and Catalytic Pyrolysis of Rice Husks. Energy, 25, 493-513. http://dx.doi.org/10.1016/S0360-5442(00)00009-8

[17] Demirbas, A. (2004) Hazelnut Shell to Hydrogen Rich Gaseous Products via Catalytic Gasification Process. Energy Source, 26, 25-33. http://dx.doi.org/10.1080/00908310490251882

[18] Vitolo, S., Seggiani, M. and Frediani, P. (1999) Catalytic Upgrading of Pyrolytic Oils to Fuel over Different Zeolites. Fuel, 78, 1147-1159. http://dx.doi.org/10.1016/S0016-2361(99)00045-9

[19] Raja, S.A., Kennedy, Z.R., Pillai, B.C. and Lee, C.L.R. (2010) Flash Pyrolysis of Jatropha Oil Cake in Electrically Heated Fluidized Bed Reactor. Energy, 35, 2819-2823.

http://dx.doi.org/10.1016/j.energy.2010.03.011

[20] Demiral, I. and Soensoz, S. (2006) Fixed-Bed Pyrolysis of Hazelnut (Corylus avellana L.) Bagasse: Influence of Pyrolysis Parameters on Product Yields. Energy Source Part A, 28, 1149-1158. http://dx.doi.org/10.1080/009083190966126

[21] Sutton, D., Kelleher, B. and Ross, J. (2001) Review of Literature on Catalysts for Biomass Gasification. Fuel Process Technology, 73, 155-173. http://dx.doi.org/10.1016/S0378-3820(01)00208-9

[22] Samolada, M., Papafotica, A. and Vasalos, I. (2000) Catalyst Evaluation for Catalytic Biomass Pyrol. Energy \& Fuels, 14, 1161-1667. http://dx.doi.org/10.1021/ef000026b

[23] Zabaniotou, A.A., Kalogiannis, G. and Kappas, E. (2000) Olive Residues (Cuttings and Kernels) Rapid Pyrolysis Product Yields and Kinetics. Biomass and Bioenergy, 18, 411-420. http://dx.doi.org/10.1016/S0961-9534(00)00002-7

[24] Demiral, I. and Sensöz, S. (2008) Structural Analysis of Pyrolysis Products from Pyrolysis of Hazelnut (Corylus avellana L.) Bagasse. Energy Sources, Part A: Recovery, Utilization, and Environmental Effects, 28, 1159-1168. http://dx.doi.org/10.1080/009083190966162

[25] Yaman, S., Şahan, M., Haykiri-açma, H., Şeşen, K. and Küçükbayrak, S. (2000) Production of Fuel Briquettes from Olive Refuse and Paper Mill Waste. Fuel Processing Technology, 68, 23-31. http://dx.doi.org/10.1016/S0378-3820(00)00111-9

[26] Mohammad, A., Same, A. and Ibrahim, R. (2014) Use of Natural and Modified Jordanian Zeolitic Tuff for Removal of Cadmium(II) from Aqueous Solutions. Jordan Journal of Civil Engineering, 8, 332-343.

[27] Pütün, A.E., Uzun, B.B., Apaydin, E. and Putun, E. (2005) Bio-Oil from Olive Oil Industry Wastes: Pyrolysis of Olive Residue under Different Conditions. Fuel Processing Technolo$g y$, 87, 25-32. http://dx.doi.org/10.1016/j.fuproc.2005.04.003 
[28] Williams, P.T. and Brindle, A.J. (2002) Catalytic Pyrolysis of Tyres: Influence of Catalyst Temperature. Fuel, 81, 2425-2434. http://dx.doi.org/10.1016/S0016-2361(02)00196-5

[29] Ucar, S. and Ozkan, A.R. (2008) Characterization of Products from the Pyrolysis of Rapeseed Oil Cake. Bioresource Technology, 99, 8771-8776.

http://dx.doi.org/10.1016/j.biortech.2008.04.040

[30] Vicente, G., Martınez, M. and Aracil, J. (2004) Integrated Biodiesel Production: A Comparison of Different Homogeneous Catalysts Systems. Bioresource Technology, 92, 297-305. http://dx.doi.org/10.1016/j.biortech.2003.08.014

Submit or recommend next manuscript to SCIRP and we will provide best service for you:

Accepting pre-submission inquiries through Email, Facebook, LinkedIn, Twitter, etc. A wide selection of journals (inclusive of 9 subjects, more than 200 journals)

Providing 24-hour high-quality service

User-friendly online submission system

Fair and swift peer-review system

Efficient typesetting and proofreading procedure

Display of the result of downloads and visits, as well as the number of cited articles Maximum dissemination of your research work

Submit your manuscript at: http://papersubmission.scirp.org/

Or contact aces@scirp.org 